\title{
Morphology and Immunological Roles of Hemocytes and Fixed Phagocytes in Black Tiger Shrimp Penaeus monodon
}

\author{
Kidchakan Supamattaya ${ }^{1 *}$, Jareeporn Ruangsii ${ }^{1}$, Toshiaki Itami $^{2}$, Vudthikorn Chitiwan ${ }^{1}$, \\ Wutiporn Phromkunthong ${ }^{1}$ and Kiyokuni Muroga ${ }^{3}$ \\ ${ }^{1}$ Aquatic Animal Health Research Center, Department of Aquatic Science, \\ Faculty of Natural Resources, Prince of Songkla University, \\ Had Yai, Songkhla 90112, Thailand \\ ${ }^{2}$ Department of Biological Production and Environmental Science, Faculty of Agriculture, \\ Miyazaki University, Miyazaki 889-2192, Japan \\ ${ }^{3}$ Graduate School of Biosphere Sciences, Hiroshima University, \\ Higashihiroshima 739-8528, Japan
}

(Received December 6, 2002)

\begin{abstract}
Morphology and immunological roles of the three distinct types of hemocytes, hyaline, small granular and large granular cells in black tiger shrimp Penaeus monodon were studied. The study of functions of these hemocytes in the elimination of injected yeast (Saccharomyces cerevisiae) or Vibrio harveyi as foreign bodies showed a rapid response against those particles. Together with fixed phagocytes, the blood cells removed the yeast through the process of phagocytosis, nodule formation and encapsulation, which occurred at almost all parts of the body. The injection of the yeast caused a marked reduction in the blood cell counts in the hemolymph during the first $1 \mathrm{~h}$. $V$. harveyi was efficiently removed within $3 \mathrm{~h}$ after injection. The granular cells (small granular and large granular hemocytes) were the major blood cells that are associated with phenoloxidase activity. The role of hemocytes and fixed phagocytes on defense mechanism in the shrimp were discussed.
\end{abstract}

Key words: Penaeus monodon, hemocyte, fixed phagocyte, phagocytosis, immune parameter, phenoloxidase, black tiger shrimp

The black tiger shrimp Penaeus monodon is aquatic species of economic potential for Thailand and several other countries around the world. The intensive culture system of the shrimp currently practiced has led to a series of problems, for example, the degradation of environment, wide spread of several diseases which seriously affect the production efficiency and the harvests (Kautsky et al., 2000). The scientists from various research disciplines have worked to solve the problems in order to maintain the sustainability of the marine shrimp culture. The significance of the study of immune system and blood components in black tiger shrimp is the utilization of the information in the rectification of the problems that arise. The information are particularly important as indicators for the black tiger shrimp

\footnotetext{
* Corresponding author

E-mail: skidchak@ratree.psu.ac.th
}

health. The information also serves the research needs in other relevant research areas. The current study was carried out to present the information on various blood cell types that are associated in the elimination of foreign bodies that indicates the immune system of the shrimp.

\section{Materials and Methods}

\section{Test Animals}

Live black tiger shrimp with average weight of 10$15 \mathrm{~g}$ from the farms with no record of diseases were used in the study. The shrimp showed transparent and intact exoskeleton with no symptoms of diseases. The slight infestation of Zoothamnium sp. was, however, noted in some shrimp. Shrimp samples were examined for bacterial infections by a standard microbiological method and also examined for white spot syndrome 
virus (WSSV) and yellow-head virus (YHV) infections by PCR and RT-PCR, respectively (Takahashi et al., 1996; Tang and Lightner, 1999). They were free from bacterial and viral infections. The juveniles were acclimated in $5 \mathrm{~m}^{3}$-concrete ponds with aeration at the Aquatic Animal Health Research Center (AAHRC), Faculty of Natural Resources, Prince of Songkla University. Fifty juveniles were stocked in each pond where the water salinity was 20 part per thousand and water temperature ranged $28-30^{\circ} \mathrm{C}$. The juveniles, prior to stocking were treated with $35 \mathrm{ppm}$ formaldehyde to eradicate the external parasites on the individuals. The feed was given 4 times daily, settled particles were removed and water was exchanged every day during the 5-7 days of acclimation period.

\section{Hemocyte structure and their roles in the elimination of foreign bodies}

The hemocytes were isolated from blood taken from the above mentioned shrimp by centrifugation at $3,600 \times$ $g$ at $4^{\circ} \mathrm{C}$ using $4 \%$ L-cysteine as an anticoagulant (Supamattaya et al., 2000a). The isolated blood cells were divided into two portions, first of which was cultured on the glass slide in 24-well plate and the cell monolayer was fixed with $0.125 \%$ glutaraldehyde for $10 \mathrm{~min}$ and stained with Giemsa for the study of cell types and external structures using a light microscope. In order to study the cell surface, the cell monolayer was also fixed with $0.125 \%$ glutaraldehyde and post-fixed with $1 \%$ $\mathrm{OsO}_{4}$ for $30 \mathrm{~min}$. The sample was dehydrated through an alcohol series and completely dried with a critical point dryer. The sample was then coated with gold particle and viewed under a scanning electron microscope (JSM-35 CF, Jeol). The second portion of blood sample was employed for the study of internal structures of the cells using a transmission electron microscope. Cell suspensions were centrifuged and cell pellet was fixed in $2.5 \%$ cacodylate buffered glutaraldehyde $\mathrm{pH} 7.4$ at $4^{\circ} \mathrm{C}$ for $1 \mathrm{~h}$ and post-fixed with $1 \% \mathrm{OsO}_{4}$ in the same buffer for $1 \mathrm{~h}$. After dehydration with ethyl alcohol and propylene oxide, they were embedded in synthetic resin (Epon-812). Semi- and ultrathin sections were stained with toluidine blue and safranin, and uranyl acetate and lead citrate, respectively, and were examined by a light microscope and an electron microscope (TEM $100 \mathrm{CX} \mathrm{II,}$ Jeol) at $80 \mathrm{KV}$ acceleration.

The cells and tissues were monitored for their capacity in the elimination of yeast as a foreign body. Powder of baker yeast (Saccharomyces cerevisiae) was dissolved in phosphate buffer at $1 \% \mathrm{w} / \mathrm{v}, 0.1$ $\mathrm{mL}$ of which was injected into the tail muscle of each experimental juvenile. Phosphate buffer alone was injected into the juvenile in control. The injected shrimp were kept in tanks under the same conditions as acclimation period, and the blood samples were collected at $1 \mathrm{~h}$-interval for the first $12 \mathrm{~h}$ period. Subsequently, the blood samples were collected at $24 \mathrm{~h}$-intervals for $96 \mathrm{~h}$ (4th day) and on the 7th, 14th and 28th days for the blood cell counts using a hemacytometer. The blood cell counts were performed at 1, 6, 9, 12, $48 \mathrm{~h}, 7$ th and 28th days for the control. The tissue samples were also collected at each blood sampling and preserved in Davidson's fixative (Bell and Lightner, 1988). The tissues were processed for the preparation of permanent slides with hematoxylin and eosin (H \& E) stain for the microscopic examinations.

\section{Immune parameters in black tiger shrimp}

The blood samples were collected from 20 juveniles, and different types of blood cells were isolated from blood samples by continuous gradient centrifugation (Supamattaya et al., 2000a). Sixty percent of Percoll solution ( $\mathrm{P}-1644$, Sigma) supplemented with $2.5 \% \mathrm{NaCl}$ was prepared by centrifuged at $8,500 \times g$ for $30 \mathrm{~min}$ at $4^{\circ} \mathrm{C}$ using a fixed angle rotor. The shrimp blood with $4 \%$ L-cycteine was gently overlaid and then centrifuged at $85 \times g$ for $10 \mathrm{~min}$ at $4^{\circ} \mathrm{C}$ using a swing-out rotor. Each band of blood cells was separated and washed three times. Hemocyte lysate (HLS) was prepared in cacodylate buffer $\mathrm{pH} 7.4$ using Vibracell ${ }^{\mathrm{TM}}$ sonicator at 30 amplitude for $10 \mathrm{~s}$ (Supamattaya et al., 2000a). The isolation of serum was carried out in the blood sampling without anticoagulant and centrifuged at $3,590 \times g$ for $2 \mathrm{~min}$ at $4^{\circ} \mathrm{C}$. The HLS and serum were analyzed for phenoloxidase activity by the method modified from Söderhäll and Hall (1984). Analyses of the phagocytic activity and superoxide ion $\left(\mathrm{O}_{2}^{-}\right)$formation of the blood cells were conducted using sampling blood from 20 juveniles. Each blood sample was mixed with anticoagulant and washed in K-199 solution (Itami et al., 1994) by $3,590 \times g$ centrifugation for $2 \min$ at $4^{\circ} \mathrm{C}$. The phagocytic activity of the blood cells was determined by the method modified from Paterson and Stewart (1974). The hemocyte monolayer was prepared for the determination of superoxide production by the modified method of Bell and Smith (1993). The clearance ability to remove bacterial cells from blood circulation of shrimp was studied using the method modified from Martin et al. (1993), by injecting Vibrio harveyi as foreign particles at a dose of $1.2 \times 10^{4} \mathrm{CFU} / \mathrm{g}$ shrimp body weight.

\section{Results}

\section{Hemocyte structure}

Under a compound microscope, the black tiger shrimp possesses three types of blood cells: Hyaline cells of minute dimension, darkly stained, with lesser proportion of granules in the cytoplasm or entirely absent. The small granular cells are of longer dimension and greater proportions of eosinophilic cytoplasmic granules and having ability to adhere to glass surface. The large granular cells are of largest dimen- 
sion with greater abundance of eosinophilic cytoplasmic granules (Fig. 1).

The scanning electron microscopy revealed the different patterns of the surface of the three types of blood cells as follows:

1) Hyaline cells: They are smallest-sized blood cells of flattened, rounded shape with smooth surface. Occasionally, they are of fusiform or crescent shape.

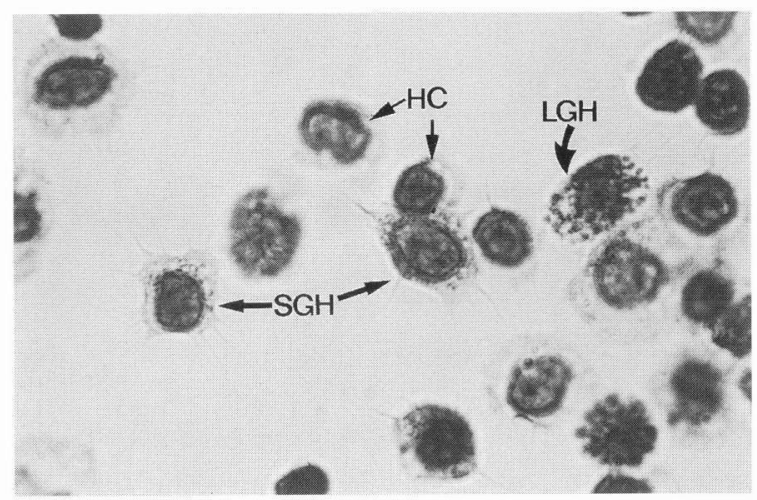

Fig. 1. Light micrograph of three types of black tiger shrimp hemocytes adhered on glass. HC: hyaline cell, SGH: small granular cell, LGH: large granular cell. Giemsa stain, Bar $=10 \mu \mathrm{m}$.

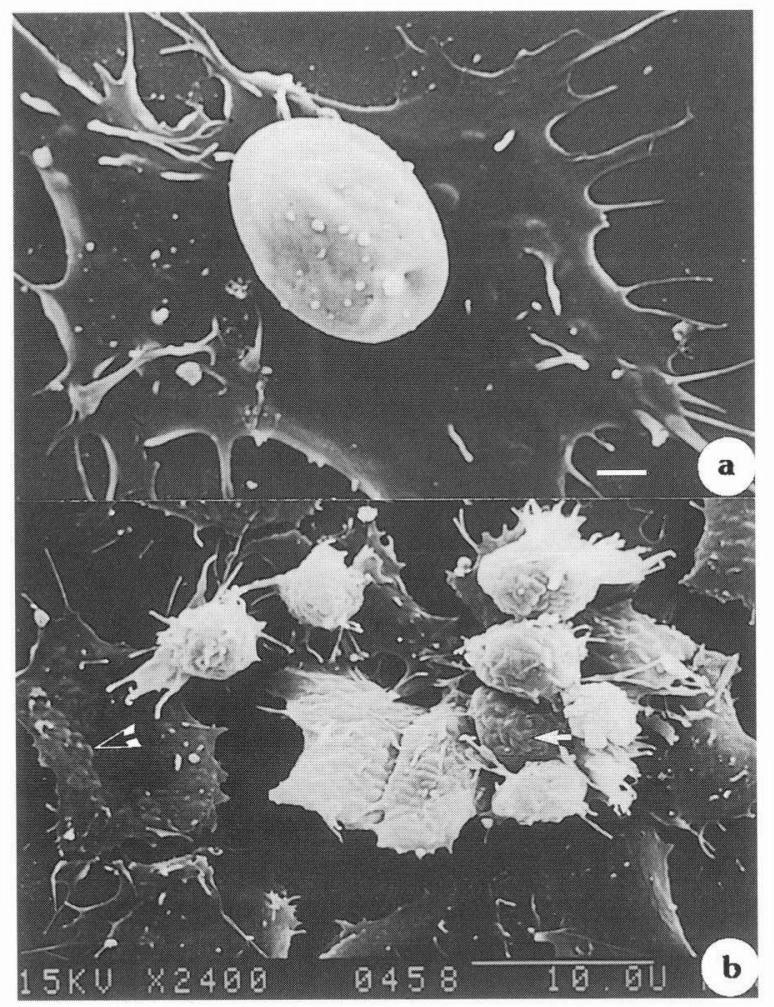

Fig. 2. Scanning electron micrograph of black tiger shrimp hemocytes. a) a hyaline cell exhibiting discoid shape on a spreading small granular cell. b) A cluster of large granular cells with abundant cytoplasmic granules (arrows). Bar $2 \mathrm{a}=1 \mathrm{~mm}, 2 \mathrm{~b}=10 \mu \mathrm{m}$.
There exists no microvilli or pseudopodia on the cell surface. The cells are 6.4-8.3 $\mu \mathrm{m}$ in diameter (in rounded cell) or 2.5-3.6 $\mu \mathrm{m}$ in width and $6.8-13.9 \mu \mathrm{m}$ in length for the crescent or fusiform shaped cells (Fig. 2a).

2) Small granular cells: The cells have large number of cell processes and pseudopodia. There appeared small number of microvilli on the cell surface. The cells are 4.2-6.8 $\mu \mathrm{m}$ in width and 9.0-14.2 $\mu \mathrm{m}$ in length.

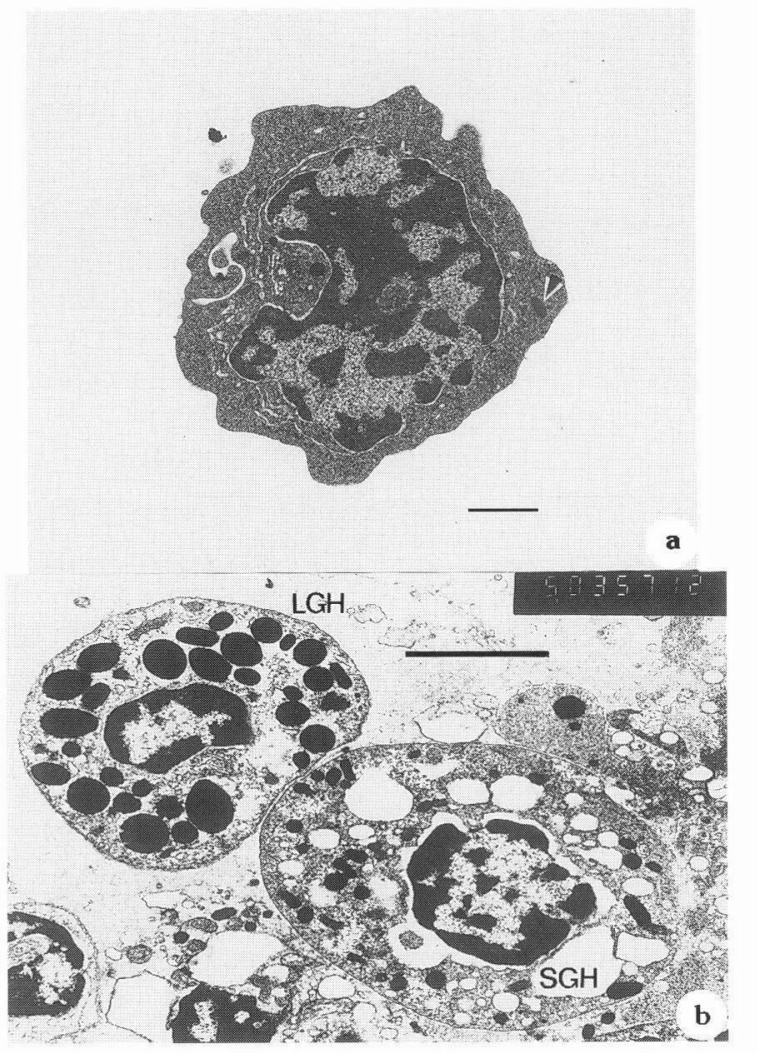

Fig. 3. Transmission electron micrograph of black tiger shrimp hemocytes. a) a hyaline cell containing large nuclei with small ratio of cytoplasm (arrowhead). b) a small granular cell (SGH) contained small number of cytoplasmic granules while a large granular cell (LGH) have abundant of granules in the cytoplasm Bar $3 a=1$ $\mathrm{mm}, 3 \mathrm{~b}=5 \mu \mathrm{m}$.

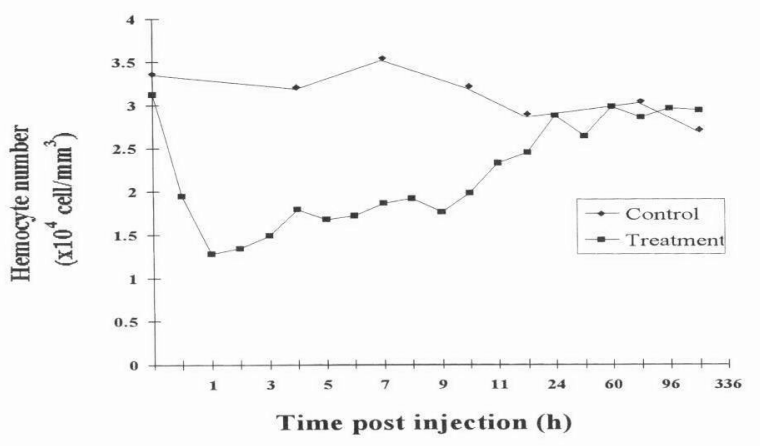

Fig. 4. The changes in shrimp hemocytic counts of Penaeus monodon after injection with yeast cells (Saccharomyces cerevisiae) 
There are small number of minute cytoplasmic granules with the size $0.6-1.0 \mu \mathrm{m}$, not obvious when observed from the cell surface by SEM (Fig. 2a).

3) Large granular cells: They are of larger dimension with similar appearance as that of small granular cells, except the great number of large cytoplasmic granules. The granules are $0.7-1.0 \mu \mathrm{m}$ in diameter and are obviously observed from cell surface. The pseudopodia or cell processes can be distinctly noted. The cells are $8-10 \mu \mathrm{m}$ in diameter, $12.2-14.6$

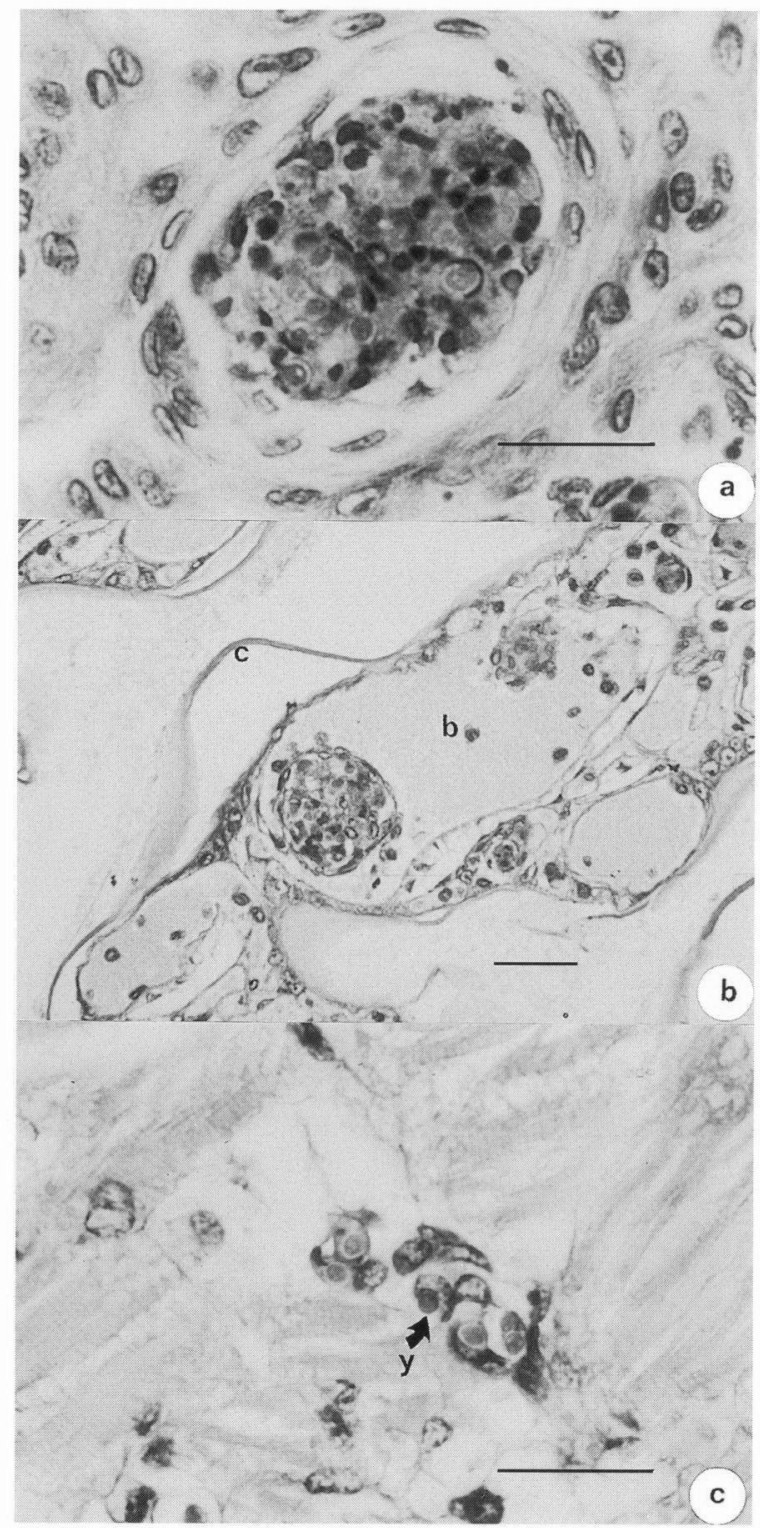

Fig. 5. a) Large encapsulation of yeast by hemocytes and fixed phagocytes occurring in the lymphoid organ of black tiger shrimp at 7 th day post-injection with yeast. b) Small nodule formation observed in the blood lacuna of gill filament. c) Yeast cells trapped by fixed phagocyte (arrow) in heart tissue. b, shrimp blood cell; c, cuticle; $y$, yeast cell. H \& E stain Bars = $50 \mu \mathrm{m}$. $\mathrm{m} \mu \mathrm{m}$ in length and $7.2-7.8 \mu \mathrm{m}$ in width (Fig. 2b).

The transmission electron microscope revealed that the hyaline cells were of smallest sizes with 5-6 $\mu \mathrm{m}$ diameter, with high nucleocytoplasmic ratio. Numerous free ribosomes or electron dense deposits were noted in the cytoplasm with small number of mitochondria and Golgi body, and rough endoplasmic reticulum (RER) or smooth endoplasmic reticulum (SER) were also seen. Few cytoplasmic granules were found in the cytoplasm (Fig. 3a). The small granular cells were of larger dimension, 7-10 $\mu \mathrm{m}$. There appeared 0.5-1 $\mu \mathrm{m}$ diameter of cytoplasmic granules scattered in the cells (Fig. 3b). The large granular cells were of largest dimension with large number of $1-1.5 \mu \mathrm{m}$ diameter granules were seen in the cytoplasm (Fig. 3b).

\section{Roles of hemocytes in elimination of yeast}

Upon the injection of yeasts to study the shrimp's responses to the foreign bodies, there was a sharp decline in the total blood cell counts within $1 \mathrm{~h}$ of injection. After that the cell counts tended to recover slowly, however, remained at a low level until $9 \mathrm{~h}$. The blood cell counts gradually increased and recovered to normal condition within $24 \mathrm{~h}$, while there were small changes in the blood cell counts for the control (Fig. 4).

The histological examination showed the scattered blood cells among the intercellular spaces and blood sinuses. The phagocytic cells were accumulated in the gills, heart, lymphoid organ and connective tissues. They were capable of performing phagocytic activity. To lesser extent, the phagocytic cells were noted in the muscular and nervous tissues. The compound microscopy showed the presence of yeasts in the blood cells as well as in the fixed phagocytes within $1 \mathrm{~h}$ of the injection of yeast. The process of phagocytosis recognized in the fixed phagocyte or blood cells began with the encroachment of single cells and larger number of blood cells encircled the foreign bodies forming a nodule within

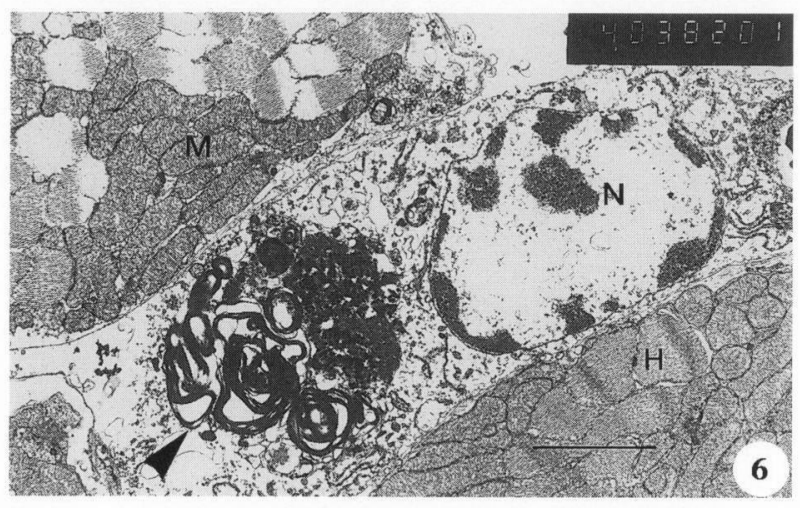

Fig. 6. Transmission electron micrograph of a fixed phagocyte in the heart of black tiger shrimp $\mathrm{N}$,nucleus of a fixed phagocyte; $\mathrm{H}$, heart muscle; $\mathrm{M}$, mitochondria of heart muscle. Note autophagic vacuole (arrowhead) $\mathrm{Bar}=$ $5 \mu \mathrm{m}$. 
Table 1. Immune defense parameters of Penaeus monodon hemocytes

\begin{tabular}{llc}
\hline \multicolumn{1}{c}{ Parameters } & Sample sources & Average* \\
\hline 1. Phenoloxidase activity & Hyaline cells & $199.0 \pm 78.8$ \\
(unit/min/mg protein) & Granular cells & $1,249.5 \pm 313.4$ \\
& Serum & $32.2 \pm 6.0$ \\
2. Phagocytic activity (\%) & Hemocytes & $26.8 \pm 12.7$ \\
3. Superoxide activity (unit) & Hemocytes & $25.4 \pm 8.3$ \\
4. Clearance ability (\%) & Blood & 98.2 \\
\hline
\end{tabular}

* Mean $\pm \mathrm{SD}, \mathrm{n}=20$.

3-9 h. The capsulation occurred between $24-48 \mathrm{~h}$ or longer where there were large number of blood cells surrounding the foreign bodies (Fig. 5a). Both the blood cells and fixed phagocytes were present in various tissues such as lymphoid organ, hepatopancreas, heart and gills (Figs. $5 b-c$ ). The electron microscopy indicated the absence of cytoplasmic granules in the fixed phagocytes, instead there existed large vacuoles, debris, and myelin figure that suggested the phagocytic activity and the formation of autophagic vacuoles (Fig. 6). The cells scattered in various tissues like heart, gills and digestive tract.

\section{Immune parameters in black tiger shrimp}

The $60 \%$ Percoll in $2.5 \%$ saline solution was used in the separation of two bands of blood cells for the determination of phenoloxidase activity. The upper band of the blood cells comprising mainly hyaline cells showed lower phenoloxidase activity, while the lower band formed by large number of granular cells showed high phenoloxidase activity. The phenoloxidase activity of serum was $32.2 \pm 6.0 \mathrm{unit} / \mathrm{min} / \mathrm{mg}$ protein. The juveniles maintained in the laboratory had the phagocytic activity of the blood cells of $26.8 \pm 12.7 \%$. The level of superoxide formed by the blood cells during the same period was $25.4 \pm 8.3$ unit for healthy individuals. The study of clearance ability of blood cells and serum in the circulating system indicated that the injected bacteria showed a sharp reduction in their density within $3 \mathrm{~h}$ postinjection. With the injection of $V$. harveyi $1.2 \times 10^{4} \mathrm{CFU} /$ $\mathrm{g}$ shrimp body weight into the tail muscle of healthy shrimp, the bacterial density in the blood dropped to about $2.2 \times 10^{2} \mathrm{CFU} / \mathrm{g}$ shrimp which accounted for $98.2 \%$ clearance ability. The results were concluded in Table 1.

\section{Discussion}

Morphology and types of blood cells in black tiger shrimp have been reported (Tsing et al., 1989; Sung et al., 1999; Van de Braak et al., 1996, 2000), although the ultrastructure of the hemocyte types have scarcely been studied. Recently it has been suggested that the hyaline cells are the young and immature hemocytes of both the large granular hemocytes and small granular hemocytes that are produced in the hematopoeitic tissue and released into the hemolymph (Van de Braak et al., 2002a). The black tiger shrimp's blood cells are differentiated into three cell types in the present study based on morphology, cell dimensions, structure of cell surface, sizes of nuclei and other cell components. However, no indication of the hyaline cells as a stem cell for the small granular cells and the large granular cells was proven in this study.

The small granular and large granular cells were well capable of pseudopodia formation which was of lesser extent for the hyaline cells. In a prolonged period, the process of degranulation or exocytosis occurred in the granular cells in which the granules totally disappeared. Hemocytes of black tiger shrimp were smaller than those found in kuruma prawn (Kondo et al., 1998) and similar in size with others. The ultrastructures studied were similar in those three types of hemocyte reported in kuruma prawn and other species (Tsing et al., 1989), for example, the electron dense deposited in the cytoplasm found in hyaline cells of black tiger shrimp was also observed in kuruma prawn (Bachere et al., 1995, Kondo et al., 1998). This structure was not found in small and large granular cells as well as fixed phagocytes.

With the injection of yeast cells into the shrimp, a marked reduction in the blood cell counts was noted within $1 \mathrm{~h}$ from the injection as a response against the invasion of foreign bodies. The histopathological examination suggested that the reduction in the blood cell counts were the result of the phagocytic activity that eventually cause the formation of nodules and capsules which will be eliminated from the body. Upon the elimination of foreign bodies from the individuals, freshly produced blood cells are recruited into the system by $24 \mathrm{~h}$ after the injection.

Fixed phagocytes located at various organs also played an important role to eliminate the foreign bodies, thus it can be said that the tissues of almost all parts of the shrimp are capable of eliminating the foreign bodies. The histological studies revealed that there were several processes through which the foreign bodies were eliminated. Such processes are phagocytosis, nodule formation and encapsulation. Three types of blood cells and fixed phagocytes are key components in all these processes. Fixed phagocytes in kuruma prawn were identified into 2 types, one located in the 
lymphoid organ and the other in the heart tissue (Kondo et al., 1998). In P. monodon injected with Vibrio, electron microscopy revealed the presence of many phagocytic cells that morphologically resemble small granular hemocytes (Van de Braak et al., 2002a). In the present study fixed phagocytes were not identified in detail but they were found through all organs but very little and with less activity in the muscle and nerve tissue.

Phenoloxidase activity from the hemocytes of black tiger shrimp was abundantly found in the granular hemocytes and less activity in hyaline cells and serum. This finding coincides to those reported in black tiger shrimp studied by Sung et al. (1998) and other penaeid shrimp such as Sicyonia ingentis, $P$. paulensis and P. japonicus (Hose et al., 1992; Seqaeira et al., 1995; Perrazzolo and Barracco, 1997; Kondo et al., 1998) as well as in other crustaceans, Astacus astacus, Procambarus clarki, Pacifastacus leniusculus and Macrobrachium rosenbergii in which the phenoloxidase activity was found in the granular hemocytes (Smith and SöderhUäll, 1983; Johanson and Söderhäll, 1985; Lanz et al., 1993; Sung et al., 1996)

The phagocytic activity may vary from species to species as reported by Paterson and Stewart (1974) who noted the phagocytic activity of $20 \%$ in lobsters and $26 \%$ in black tiger shrimp. The black tiger shrimp's blood also showed $98.2 \%$ clearance ability against $V$. harveyi within $3 \mathrm{~h}$ in healthy shrimp or the shrimp from under proper management of the farms. Van de Braak et al. (2002b) also reported the hemocytes and lymphoid organ plays an importance role to remove the bacterial cell from blood circulation in black tiger shrimp ( $P$. monodon). Sritunyaluksana (1995) reported similar results in black tiger shrimp that the whole blood had higher clearance activity with over $80 \%$ in the elimination of bacteria while the separated blood cells had lower of $46 \%$ and even less of $5 \%$ in separated serum. It indicated that the blood components including humoral and cellular components as well as fixed phagocytes had an important roles in the phagocytic activity. In kuruma prawn it was also found that serum enhance the phagocytic activity (Kondo et al., 1992). The phagocytic activity, however, also depends on shrimp culture condition, for example shrimp exposed to low oxygen level and infectious disease exhibited low phagocytic activity (Supamattaya et al., 2000b).

\section{Acknowledgements}

Authors would like to thank to National Center for Genetic Engineering and Biotechnology, Thailand and NRCT-JSPS for research funding.

\section{References}

Bachere, E., E. Mialhe and J. Rodriguez. (1995): Identification of defence effectors in the haemolymph of crustaceans with particular reference to the shrimp Penaeus japonicus (Bate): prospecta and applications. Fish Shellfish Immunol., 5, 597-612.

Bell, T. A. and D. V. Lightner (1988): A handbook of normal penaeid shrimp histology. Allen Press, Kansas, $114 \mathrm{p}$.

Bell, K. L. and V. J. Smith (1993): In vitro superoxide production by hyaline cells of the shore crab Carinus maenas (L). Dev. Comp. Immunol., 17, 211-219.

Hose, J.E., G.G. Martin, S. Tui and N. McKrell (1992): Partterns of hemocyte production and release throughout the molt cycle in the penaeid shrimp Sicyonia ingentis. Biol. Bull., 183, 185-199.

Itami, T., Y. Takahashi, E. Tsuchihira and H. Egusa (1994) : Enhancement of disease resistant of kuruma prawn Penaeus japonicus increase in phagocytic activity of prawn hemocytes after oral administration of $\beta-1,3$-glucan (Schizophyllan). In "The third Asian Fisheries Forum" (ed. by L. M. Chou, A. D. Munro, T. J. Lam, TW. Chen, L. K. K. Cheong, J. K.Ding, K. K. Hooi, H. W. Khoo, V. P. E. Pang, K. F. Shim and C. H. Tan. Asian Fish. Soc, Manila, Philippines, pp. 375-378.

Johanson, M. W. and K. Söderhäll (1985): Exocytosis of the prophenoloxidase activating system from crayfish haemocytes. J. Comp. Physiol., 156, 175-181.

Kautsky, N., P. Ronnback, M. Tedengren and M. Troell (2000): Ecosystem prospective on management of disease in shrimp pond farming. Aquaculture, 191, 145-161.

Kondo, M., H. Matsuyama and T. Yano (1992): The opsonic effect of lectin on phagocytosis by hemocytes of kuruma prawn, Penaeus japonicus. Fish Pathol., 27, 217-222. (In Japanese with English abstract)

Kondo, M., T. Itami, Y. Takahashi, R. Fujii and S. Tomonaga (1998): Ultrastructure and cytochemical ccharacteristics of phagocytes in kuruma prawn. Fish Pathol., 33, 421-427.

Lanz, H., V. Tsutsumi and H. Arechiga (1993): Morphological and biochemical characterization of Procambarus clarki blood cells. Dev. Comp. Immunol., 17, 389-397.

Martin, G. G., D. Poole, C. Poole, J.E. Hose, M. Arias, L. Reynolds, N. MaKrell and A. Whang (1993): Clearance of bacteria injected into the hemolymph of the penaeid shrimp, Sicyonia ingentis. J. Invertebr. Pathol., 62, 308315.

Paterson, W. D. and J. E. Stewart (1974): In vitro phagocytosis by hemocytes of the American lobster (Homarus americanus). J. Fish. Res. Board Can., 31, 1051-1056.

Perrazzolo, L. M. and M. A. Barracco (1997): The prophenoloxidase activating system of the shrimp Penaeus paulensis and associated factors. Dev. Comp. Immunol., 21, 385395.

Sequeira, T., M. Vilanova, A. Lobo-Da-Cunha, L. Baldaia and M. Arala-Chaves. (1995): Flow cytometric analysis of moltrelated changes in hemocyte type in male and female Penaeus japonicus. Biol. Bull., 198, 376-380.

Smith, V. J. and K. Söderhäll (1983): Induction of degranulation and lysis of haemocytes in the freshwater crayfish, Astacus astacus by components of the prophenoloxidase activating system in vitro. Cell Tiss. Res., 233, 295-303.

Söderhäll, K. and L. Hall (1984): Lipopolysaccharide-induced activation of prophenoloxidase activating system in crayfish hemocyte lysate. Biochem. Biophys. Acta., 797, 99-104.

Sritunyalucksana, K. (1995): Study of the humoral defense factors in the black tiger prawn, Penaeus monodon. MS. Thesis, Mahidol University, Bangkok. $148 \mathrm{p}$.

Sung, H. H., Y. L. Yang and Y. L. Song (1996): Enhancement of microbiocidal activity in the black tiger shrimp Penaeus monodon via immunostimulation J. Crustacean Biol., 16, 
278-284.

Sung, H. H., H. J. Chang, C. H. Her, J. C. Chang and Y. L. Song (1998): Phenoloxidase activating of hemocytes derived from Penaeus monodon and Macrobrachium rosenbergii. J. Invertebr. Pathol., 71, 26-33.

Sung, H. H., P. P. Wu and Y. L. Song (1999): Chracterisation of monoclonal antibodies to haemocyte subpopulations of tiger shrimp (Penaeus monodon): immunochemical differentiation of three major hemocyte types. Fish Shellfish Immunol., 9, 167-179.

Supamattaya, K., U. Ekpanithanpong, T. Itami and J. Kasornchadra (2000a): Techniques on immunological assessment and blood component in black tiger shrimp, Penaeus monodon Fabricius. Songklanakarin J. Sci. Technol., 22, 561-580.

Supamattaya, K, J. Ruangsri, S. Kiriratnikom and N. Suanyuk (2000b): Effect of water temperature, DO and $\mathrm{pH}$ on immuno-physiological function in black tiger shrimp (Penaeus monodon Fabricius). Songklanakarin J. Sci. Technol., 22, 605-614.

Takahashi, Y., T.Itami, M. Maeda, N. Suzuki, J. Kasornchandra, K. Supamattaya, R. Khongpradit, S. Boonyaratpalin, M. Kondo, K. Kawai, R. Kusuda, I. Hirono and T. Aoki (1996): Polymerase chain reaction (PCR) of bacilliform virus (RV-PJ) DNA in Penaeus japonicus Bate and systemic ectodermal and mesodermal baculovirus (SEMBV) in Penaeus monodon Fabricius. J. Fish Dis., 19, 399-403.
Tang, K. F. J. and D. V. Lightner (1999): A yellow head virus gene probe: nucleotide sequence and application for in situ hybridization. Dis. Aquat. Org., 35, 165-173.

Tsing, A., J. M. Srcier and M. Bréhelin. (1989): Hemocytes of Penaeid and Palaemonid shrimps: Morphology, cytochemistry and hemograms. J. Invetebr. Pathol., 53, 64-77.

Van de Braak, C. B. T., R. Faber and J. H. Boon (1996): Cellular and humoral characteristics of Penaeus monodon (Fabricius, 1798) haemolymph. Comp. Haematol. Int., 6, 194203.

Van de Braak, C. B. T., N. Taverne, M. H. A. Botterblom, W. P. W. Van der Knaap and J. H. W. M. Rombout. (2000): Characterization of different morphological features of black tiger shrimp haemocytes using monoclonal antibodies. Fish Shellfish Immunol., 10, 515-530.

Van de Braak, C. B. T., M. H. A. Botterblom, W. Liu, N. Taverne, W. P. W. van de Knaap and J. H. W. M. Rombout (2002a): The role of the haematopoietic tissue in haemocyte production and maturation in the black tiger shrimp (Penaeus monodon). Fish Shellfish Immunol., 12, 253-272.

Van de Braak, C. B. T., M. H. A. Botterblom, N. Taverne, W. B. van Muiswinkel, J.H.W.M. Rombout and W.P.W. van de Knaap (2002b): The roles of haemocytes and the lymphoid organ in the clearance of injected Vibrio bacteria in Penaeus monodon shrimp. Fish Shellfish Immunol., 13, 239-309. 